\title{
Hint Topraklarında Türk Kütüphaneciliğinin İzlerini Aramak: Kütüphanelerin Gelişiminde Babürlü Hükümdarlarının Rolleri (1526-1707)
}

\author{
Searching for Traces of Turkish Librarianship in Indian Lands: Roles of Mughal \\ Rulers in the Development of Libraries (1526-1707)
}

\section{Emre Yürük*}

$\ddot{\boldsymbol{O}} \boldsymbol{z}$

Bu çalışmada, Türkler tarafindan Hint Yarımadası'nda kurulan Babür İmparatorluğu'nda 1526-1707 yilları arasında hüküm süren padişahların kütüphanelere ve kütüphaneciliğe dair faaliyetleri incelenmiştir. Padişahların entelektüel yapılarına değinilerek kütüphanelerin oluşturulması ve geliştirilmesinde ne tür katkıları olduğu ele alınmıştır. Bu dönemde eski eserlerin tercüme edilmesiyle kütüphanelerin zenginleşmesi, nakkaşlıkla birlikte kitaplarda görselliğin artması, ciltçilik sayesinde kitapların uzun süre korunması gibi kütüphanecilikle ilintili faaliyetlerin ön planda tutulduğu görülmüştür. Ayrıca fethedilen yerlerdeki kütüphanelerin merkeze taşınmasıyla saray kütüphanesinin geliştirildiği dikkat çekmektedir. Babür Şah ve Hümayun ile temelleri atılan, Ekber Şah ile sistemleştirilen, Cihangir, Şah Cihan ve Evrengzib ile geliştirilen saray kütüphanesinin, döneminin eşsiz zenginliğe bir sahip kütüphanesi olduğu da ortaya konmaya çalışılmıştır.

Anahtar Sözcükler: Kütüphane; kütüphanecilik; Babür Imparatorluğu; Hindistan.

\begin{abstract}
In this study, the activities of the sultans who reigned between the years 1526-1707 in the Mughal Empire founded by the Turks in the Indian Peninsula were examined. By mentioning the intellectual structures of the sultans, what kind of contributions they have made in the creation and development of libraries are discussed. It has been observed that activities related to librarianship such as enrichment of libraries with the translation of old works, the increasing visibility in books together with embroidery and long-term preservation of books thanks to bookbinding were prioritised. It is also worth noting that the palace library was developed by moving the libraries in the conquered places to the centre. It was also revealed that the palace library, whose foundations were laid with Babur Shah and Hümayun, systematized with Akbar Shah, developed with Jahangir, Shah Jahan and Aurangzeb, was a library with a unique richness.
\end{abstract}

Keywords: Library; librarianship; Mughal Empire; India.

\footnotetext{
* Doktora Öğrencisi. Jawaharlal Nehru Üniversitesi Uluslararası İlişkiler Bölümü Batı Asya Çalışmaları Merkezi. E-posta: emryrk@gmail.com Orcid Id: https://orcid.org/0000-0002-6798-1048

Phd Student. Javaharlal Nehru University School of International Studies Center for East Asian Studies.
} 
Hint Topraklarında Türk Kütüphaneciliğinin İzlerini Aramak: Kütüphanelerin Gelişiminde Babürlü Hükümdarlarının Rolleri (1526-1707)

Searching for Traces of Turkish Librarianship in Indian Lands: Roles of Mughal Rulers in the Development of

\section{Giriş}

İnsanoğlu Mezopotamya'dan İndus'a, Çin'den antik Mısır'a, Eski Yunan'dan Roma'ya nerede medeniyet kurma girişiminde bulunsa kütüphaneler inşa edip onları kitaplarla doldurma gayretinde olmuştur. Böylece elde edilen bilgi birikimi kütüphaneler aracılığıyla nesilde nesile aktarılarak gelecekte yapılacak olan ilmî çalışmalara kaynaklık etmesi sağlanmıştır. Türkler gibi coğrafi şartların yerleşik yaşama geçmeye müsaade etmediği toplumlarda ise kütüphanecilik faaliyetlerinin başlangıçta az olmasının sebebi göçebe olarak sürdürülen yaşam mücadelesi sonucunda güçlü bir askerî kültürün oluşumuna öncelik verilmesi, bu doğrultuda, kitapların saklanıp, ilmî faaliyetlerin gerçekleştirileceği kütüphanelerin oluşturulmasının ikinci planda kalmasıdır. Ancak kültürel faaliyetleri önemsememenin Türklerin karakterinin bir parçası olmadığı aşikârdır. Nitekim değişen şartlar neticesinde dünyanın birçok bölgesine göç etmek zorunda kalan Türk boyları, İran'da, Orta Doğu'da, Afrika'da, Karadeniz'in kuzeyinde, Anadolu'da, Balkanlar'da, Çin'de ve Hint Yarımadası'nda devletler kurarak buralarda kültürel anlamda kalıcı ve derin izler bırakmışlardır.

Coğrafi açıdan bakıldığında Türklerin anavatanı Orta Asya'ya yakın olan, Türklere ait kültürel izlerin çok fazla bulunduğu yerlerden birisi Hint Yarımadası'dır. Bu noktada, Türklerin Hindistan' daki kültürel faaliyetlerinin meşakkatli bir sürecin sonunda ortaya çıktığını belirtmek gerekmektedir. Türklerin kendilerini Hint toplumuna kabul ettirememeleri bir yana özellikle Gazneli Mahmud'un Hindistan'a düzenlediği on yedi sefer ile birlikte Hint toplumunun gözünde Türkler, yağmacı, barbar ve tapınakları yok eden bir millet olarak görülmüştür (Chandra, 1990, s. 46-47). ${ }^{1}$ Ancak zamanla Hint Yarımadası'nda yerleşik bir düzen kurarak göçebe kültürden uzak bir hayat yaşamaya başlayan Türkler, siyasî, idarî, eğitim, kültür ve sanat alanlarında önemli gelişmelere imza atmıştır. Türk, Hint ve İslam sentezinin bir arada hayat bulduğu Hint Yarımadası'nda yapılan bu faaliyetler ise Hint halkının gözünde Türklerin imajını olumlu yönde düzeltmiştir (Ayyubi ve Kaymaz, 1964, s. 278; Chandra, 2017, s. 145).

Türklerin kültürel anlamda Hindistan'a en fazla katkısı Babür İmparatorluğu'nun kurulması ile olmuştur. Babür Şah tarafından 1526 yılında kurulan Babür İmparatorluğu 1707 yılına kadar geçen sürede siyasî anlamda Hint Yarımadası'nın büyük bir bölümünü kontrol etmeyi başarmıştır. Bu başarının ardındaki önemli sebeplerden birisi dönemin hükümdarları Babür Şah, Hümayun, Ekber Şah, Cihangir, Şah Cihan ve Evrengzib'in askerî ve siyasî yönden başarılı bir yönetim sergilemeleridir. Bu hükümdarlar askerî ve siyasî yeteneklerinin yanı sıra kültürel ve entelektüel anlamda birikimli olup, eğitim, kitap, kütüphane ve bağlı alanlara özel ilgi duydukları da dönemin yazılı eserlerinden anlaşılmaktadır.

Babür İmparatorluğu'nun siyasî, askerî ve hatta mimarî tarihi üzerine sayısız eser bulunmasına rağmen imparatorluğun saray kütüphanesi başta olmak üzere ülkedeki kütüphaneler ve hükümdarların kütüphanecilik faaliyetleriyle ilgili yapılan çalışmalar yok

\footnotetext{
${ }^{1}$ Burada açıklık getirilmesi gereken durum Gazneli Mahmud'un Hint topraklarını kendisi ve tebaası için yaşam alanı görmemesiydi. Bundan dolayı Gazneli Mahmut, Hint topraklarına akınlar yaparak ganimetler elde ettikten sonra geri dönmüştür. Ancak bu durum Gazneli Mahmut'un bilime, eğitime, âlimlere ve kitaplara önem vermediği anlamına gelmemektedir. Hint tarihinin önemli kronik yazarlarından Ferişta, Gazneli Mahmud'un sarayından bahsederken "dünyada hiç kimsenin sahip olamayacağı kadar eğitimli adama sahiptir" diyerek aslında Gazneli Mahmud'un eğitime verdiği öneme işaret etmektedir (Law, 1916, s. 11).
} 
denecek kadar azdır. Hâlbuki insanlık tarihi kadar eskiye uzanan kütüphanelerin hangi coğrafyada hangi milletler tarafından kurulup geliştirildiği, içerisinde ne gibi kitapların bulunduğu, ilmî ve kültürel yönden toplumlara nasıl katkı sağladıkları araştırılmayı bekleyen konulardan biridir. Özellikle Türkler gibi dünyanın dört bir tarafına dağılıp medeniyetler kurmuş bir milletin eğitim ve kültür alanında yaptığı katkıları, yazılan eserler ve bunların korunduğu kütüphaneler vasıtasıyla öğrenmekteyiz. Bu sebeplerden ötürü Hint Yarımadası'na uzun yıllar egemen olmuş Türklerin, kütüphanelere ve kütüphanecilik faaliyetlerine dair araştırmaların yapılması Türk tarihi açısından farklı bir önem arz etmektedir.

Bu çalışmada, bir Türk devleti olarak Hindistan'da kurulan Babür İmparatorluğu'nun 1526-1707 yılları arasında hüküm süren padişahları Babür Şah, Hümayun, Ekber Şah, Cihangir, Şah Cihan ve Evrengzib'in kütüphanelere olan ilgileri ele alınmaktadır. Çalışmada ağırlıklı olarak hükümdarların entelektüel kişilikleri, ilgi duydukları kitaplar ve kitaplarla ilgili sanatlar, kütüphanelerin gelişimine katkıları ele alınmaktadır. Çalışmanın kaynak eserler ve dönemin kronik yazarlarının verdiği bilgiler çerçevesinde incelenerek değerlendirilmesi amaçlanmaktadır.

\section{Babür Şah'ın Kütüphanecilik ve Kütüphanelerle Ilgili Faaliyetleri}

Anne tarafından Moğol hükümdarı Cengiz Han, baba tarafından Türk hükümdar Emir Timur'un soyundan gelen Babür Şah, babası Mirza Ömer Şeyh'in beklenmedik ölümü üzerine 1494 yılında daha on bir yaşındayken Fergana'da tahta çıkmıştır (Chandra, 2003, s. 16). Babür Şah, hayatının büyük bir bölümünü savaş meydanlarında veya sürgün olarak geçirmesine rağmen iyi bir eğitim almış ve kendini geliştirmiş bir kişiydi. Çocukluğunun geçtiği Andican bölgesinde yaşayan halk gibi kendisi de Çağatay Türkçesi'ni konuşmaktaydı. Kaleme aldığı ve yaşadıklarını detaylı bir şekilde anlatmaya çalıştığı Babürname adlı eserini Çağatay Türkçesi ile yazan Babür Şah dönemin ünlü şairi Ali Şir Nevâî’den sonra edebî anlamda Çağatay Türkçesi'ni en iyi kullanan kişi olarak bilinmektedir (Dale, 2018, s. 27). Hat sanatına ayrı bir önem veren Babür Şah'ın kendi icat ettiği Hatt-ı Babürî adlı bir yazı da bulunmaktadır (AbdulQadir Ibn-i-Muluk Shah, 1990, s. 450A). Hatta bu yazı ile yazdığı bir Kur'an-1 Kerim'i Mekke'ye yolladığı bilinmektedir (Alparslan, 1977, s. 207). Babür Şah, Hanefilik üzerine Mubaiyyin adını verdiği bir kitap da yazmıştır (Abdul-Qadir Ibn-i-Muluk Shah, 1990, s. 450A).

Babürname adlı eser incelendiğinde Babür Şah'1n kitaplara ve kütüphanesinin gelişmesine ciddi derecede önem verdiği görülmektedir. 1525 yılında mağlup ettiği Gazi Han'ın kişisel kütüphanesinde iyi kitaplar bulup onlara sahip olmayı beklese de, ummadığı bir kütüphaneyle karşılaşmadığını şu sözlerle belirtmektedir:

“Gazi Han'ın kütüphanesine geldim. Birkaç nefis kitap çıktı. Bir kaçını Hümayun'a verdim ve bir kaçını da Kamran'a gönderdim. Mollayane kitaplar da pek çoktu; fakat o kadar gözü celbedecek nefis kitap yoktu." (Babür, 2000, s. 416).

Panipat Savaşı’yla birlikte Hindistan'ı yurt edinen Babür Şah, 1526 yılında burada Babür İmparatorluğu adına ilk kütüphaneyi kurmuştur. Atalarının özel koleksiyonlarından seçtiği nadir el yazmaları ile yine atalarına ait kütüphanelerde bulunan resimlerin birçoğunu Hindistan'a getirmiştir (Patel ve Kumar, 2001, s. 6). Kendi emekleriyle oluşturduğu saray kütüphanesi dışında hükümdarlığı sırasında Şuhrat-l-Am adı verilen bayındırlık hizmetleri 
Hint Topraklarında Türk Kütüphaneciliğinin İzlerini Aramak: Kütüphanelerin Gelişiminde Babürlü Hükümdarlarının Rolleri (1526-1707)

Searching for Traces of Turkish Librarianship in Indian Lands: Roles of Mughal Rulers in the Development of

yapan birimin görevlerinden biri mektep ve medreseler açmaktı. Açılan her medresenin genellikle bir kütüphanesi bulunduğundan ülke genelinde küçük çaplı da olsa bir kütüphane ağı oluşturulmuştur (Datta, 1960, s. 61).

Eserinde Hindistan hakkında değerli bilgiler veren Babür Şah, Hindistan'ın ikliminden bahsederken çok rutubetli olduğunu bu yüzden nemli havanın kitaplara zarar verdiğinden yakınmıştır (Babür, 2000, s. 468). Kütüphanesini sefer zamanlarında dahi yanında taşıyan Babür Şah, onların korunması konusunda sıkıntılar yaşamıştır. Hindistan'daki son savaşı olan Ghagra Savaşı'nı kazandığı günlerde Hint ikliminin meşhur muson yağmurlarına yakalanmış ve kendi tabiriyle "mevsim yağmuru bulutları boşanıp, bir anda öyle tufan oldu ve öyle müthiş bir firtına koptu ki, yıkılmamış hemen hiç bir çadır kalmadı" sözleriyle durumun vehametini ifade etmiştir (Babür, 2000, s. 603). Yağmur esnasında çadırı içerisinde yazı yazmakta olan Babür Şah ne olduğunu anlamadan yıkılan çadırın altında kalmış, kitaplarını ve yazdıklarını koruma derdine düşerek zor da olsa hepsini toplamıştır. Babür Şah yağmur dindikten sonra bir çadır kurdurarak içerisinde mumlar yaktırıp sabaha kadar uyumadan kâğıtları, yazdıklarını ve kitaplarını kurtarmakla meşgul olmuştur (Babür, 2000, s. 603-604).

Babür Şah, sadece kütüphanesiyle değil aynı zamanda ilim insanlarıyla da seferlere katılırmıştır. Örneğin, dönemin önde gelen âlimlerinden Habibü 's-Siyer müellifi İranlı tarihçi Handmir'i maiyetine alıp Bengal seferine onunla çıkmıştır. Herat'ta doğan Handmir, Babür Şah'ın övgüyle bahsettiği Ali Şir Nevai'nin ve dedesi Mirhand'ın tedrisatından geçmiş bir âlimdi (Aka, 1997, s. 550-552; Elliot, 1872, s. 141-143).

Babür Şah, seferlerde olmadığı zamanlarda zamanının büyük kısmını kütüphanesinde geçirirdi. Öyle ki ömrünün son zamanlarında sürekli hastalanan, yüksek ateş ve halsizlikle boğuşan Babür Şah, cemaatle namaza katılamadığında namazını kütüphanesinde kılardı (Babür, 2000, s. 558).

Babür Şah, 1526 yılında Afgan hükümdar İbrahim Lodi’ye karşı Panipat'ta aldığı zaferle Türk ve Hint tarihinde derin izler bırakan Babür İmparatorluğu'nun temellerini atmıştır. Askerî açıdan hem ateşli silah teknolojisini Hindistan'a getirmesi hem de burada girdiği her savaşı kazanması onun başarılı bir komutan olarak anılmasını sağlamıştır. Yanı sıra, Hindistan'1 yurt olarak görüp mektepler, medreseler ve kütüphaneler inşa ettirmesi, ilim adamlarını Hindistan'a davet etmesi ve kişisel kütüphanesini geliştirmek için çaba sarf etmesi Babür Şah'ın eğitime verdiği önemi göstermektedir. Hindistan macerası dört y1l süren Babür Şah beklenmedik bir şekilde genç yaşta vefat etmiştir. Hayatının büyük bir bölümünü savaşlar, sürgünler içerisinde geçirmesine rağmen kitap ve kütüphane tutkusundan vazgeçmediği bilinen Babür Şah'ın yazdığı Babürname adlı eseriyle sadece dönemin askerî ve siyasî olaylarını değil aynı zamanda Hint coğrafyasında görülen mevsimleri, hayvanları, ağaçları, meyveleri, dini inanışları vb. günlük hayata ait olayları öğrenmemizi sağlamıştır.

\section{Kütüphanede Gelen Ölüm: Hümayun Şah}

Babür Şah'ın ölümüyle birlikte büyük oğlu olan Hümayun 1530 yılında tahta geçmiştir. Tipkı babası gibi hayatının büyük bir bölümü savaş meydanlarında geçiren Hümayun özellikle Şir Şah Suri ve Gücerat hâkimi Bahadır Şah ile giriştiği mücadelelerde askerî açıdan çok 
yıpranmıştır (Jouher, 1832, s. 3-11). Nihayetinde Şir Şah Suri tarafından 1539 Chausa (Çavsa) ve 1540 yılında Kannauj (Kannevc) Savaşları'nda aldığı ağır yenilgiler sonrası yaklaşık 15 yıllık bir sürgün hayatı yaşamıştır. Safevi hükümdarı Tahmasb'a sığınıp ondan aldığı askerî destek sayesinde Kabil ve Bedahşan'1 ele geçirmiştir. Asıl amacı Hindistan'1 geri almak olan Hümayun'un aradığı firsatı Şir Şah'ın varislerinin taht kavgasıyla bulmuş ve İskender Şah Suri ile 1555 yılında yapılan Sirhind Savaşı'nı kazanarak Hindistan'da tekrar hâkimiyetini tesis etmiştir (Konukçu, 1998, s. 482). Hümayun, uzun bir süre siyasî anlamda istikrar sağlayamasa da eğitime, kitaplara ve kütüphanelere olan ilgisi hep canlı kalmıştır.

Döneme ait kaynaklardan edinilen bilgilere göre Hümayun Şah kitaplarına düşkün, sefer zamanında dahi onları yanında getirmeyi ihmal etmezdi. Hatta Şir Şah Suri'ye yenilip kaçarken bile kütüphanecisi ve kitaplarını peşinde götürmüştür. Kaçış esnasında Cambay’da kamp yaptığı sıralarda ormanda yaşayan Koli ve Gavar adında kabileler gece vakti ansızın bir baskın yaparak Hümayun Şah'ın kampını yağmalamış, yağma esnasında Molla Sultan Ali tarafından tercüme edilen, Üstad Bihzad tarafından resmedilen Timur-nama adlı nadide eser de çalınmış, ancak daha sonra bulunup geri alınmıştır (Abu'l Fazl Allami, 1907, s. 309-310).

Hümayun Şah kütüphane kurma konusunda ilgili ve istekliydi. 1541 yılında Şir Şah Suri tarafından Delhi'deki Purana Qila'da yapılan ve Sher Mandal adıyla bilinen eğlence evini kütüphaneye çevirmiştir (Law, 1916, s. 133). Bunun dişında Hümayun Şah'ın Agra'da yaptırdığı Khana-i Tilism (Sihir Evi) Türk ve Hint kütüphaneciliği açısından değerli bir yapıdır. Üç binanın merkezinde yer alan ve Khana-i Sadat olarak bilinen bölüm bir kütüphaneye sahipti. Kütüphanede kitaplar, yaldızlı divitler, resimli kitaplar ve hat sanatına dair güzel örnekler bulunmaktaydı (Patel ve Kumar, 2001, s. 6). Diğer taraftan Hümayun Şah Delhi'de ve Agra'da olmak üzere iki tane medrese kurdurdu (Law, 1916, s. 133-134). Medreselerin yanlarında kütüphaneler olduğu dikkate alındığında kütüphanecilik faaliyetlerinin Hümayun Şah zamanında gelişmeye devam ettiğini söylemek mümkündür.

Hümayun Şah iyi bir eğitim almasının yanı sıra sanat ve ilimle de yakından ilgiliydi. Tarihçi Ferişta Hümayun Şah'ın kendisini özellikle astronomi ve coğrafyaya adadığını belirtmiştir (Mahomed Kasim Ferishta, 1909, s. 70-71). Ayrıca etrafinda eğitimli insanlar bulundurmaya özen göstererek onlarla yeri geldiğinde tartışmalara da katılırdı (Mahomed Kasim Ferishta, 1909, s. 178-179). Bu bağlamda Hümayun'un değer verdiği ünlü Türk denizcisi Seydi Ali Reis ile olan muhabbetine değinmek yerinde olacaktır. Seydi Ali Reis Basra'dan Osmanlı donanmasını alıp Süveyş'e getirmeye niyetlendiği sırada yolda firtınaya kapılıp Hint Yarımadası'na sürüklenmiştir. Seydi Ali Reis, Hint Yarımadası'na ayak bastıktan sonra kara yoluyla İstanbul'a dönmeyi amaçlasa da, uzun maceralardan sonra Hümayun Şah ile tanışmış ve okuduğu gazeller ile Hümayun'un ilgisini çekmiştir. Hindistan'da kalması için Hümayun tarafından tımar teklif edilen Seydi Ali Reis'in teklifi kabul etmemesi üzerine muson yağmurlarını bahanesiyle en azından bir yıl daha Hindistan'da vakit geçirmesi için ısrar edilmiştir (Seydi Ali Reis, 1975, s. 68).

Hümayun Şah bir akşamüstü temiz hava almak için Sher Mandal'daki kütüphanesinin terasına çıkmış, bir zaman sonra merdivenlerden inerken ezan okunmaya başlayınca ezana hürmeten merdivende oturup bitmesini beklemiş, ezan bittikten sonra tekrar ayağa kalkmak isteyince dengesini kaybedip kafa üstü yere düşmüştür. Vücudunun birçok yerinde kırık 
Hint Topraklarında Türk Kütüphaneciliğinin İzlerini Aramak: Kütüphanelerin Gelişiminde Babürlü Hükümdarlarının Rolleri (1526-1707)

Searching for Traces of Turkish Librarianship in Indian Lands: Roles of Mughal Rulers in the Development of

meydana gelen Hümayun Şah, yapılan müdahalelere rağmen hayatını kaybedince 1556 yılında yerine oğlu Ekber Şah geçmiş̧tir (Jouher, 1832, s. 120; Seydi Ali Reis, 1975, s. 79).

\section{Kütüphanelerin Gelişimi: Ekber Şah'ın Çabaları}

Ekber Şah genç olmanın verdiği enerjiyle Kuzey Hindistan'ın büyük bir bölümünü fethetmeyi başarmıştır. Askerî başarılar neticesinde bölgeye gelen barış ve istikrar, ekonomik anlamda insanları rahatlatırken kültürel hayatın da canlanması sağlanmış, resim, minyatür, edebiyat, çeviri faaliyetleri artarken yeni eğitim öğretim yerleri ve kütüphaneler kurulmaya başlanmıştır.

Ekber Şah, babası ve dedesinin aksine okuma yazma bilmeyen, ancak öğrenmeye hevesli, ve kendini geliştiren bir kişiydi. Oğlu Cihangir yazdığı eserinde babasını şu sözlerle tanımlamaktadır:

“Babam (Ekber), başta Panditler ve Hindistan'ın eğitimli kişileri olmak üzere her dinden ve inançtan bilgili insanlarla söylemler yapardı. Okuma yazma bilmemesine rağmen, ĕgitimli ve zeki insanlarla sürekli ilişki kurmuş ve onlarla yaptığı konuşmalarda hiç kimse onun ĕ̆itimsiz olduğunu anlayamazd"” (Jahangir, 1909, s. 33).

Ekber Şah döneminde her Cuma, Pazar ve kutsal kabul edilen günlerde Sofiler, Doktorlar, Vaizler, Hukukçular, Sünniler, Şiiler, Cainler, Budistler, Çarbaklar, Hristiyanlar, Yahudiler, Zoroastrianlar ve her inançtan belirli bir bilgi seviyesine sahip kişiler saraya davet edilerek fikir özgürlüğü çerçevesinde korkusuzca kendi argümanlarını savunur, bilimin temel noktaları, tarihten merak edilenler, doğa kanunları ve daha nice konu bu toplantılarda konuşulup tartışılırdı (Law, 1916, s. 145).

Ebu'l Fazl el-Âllamî'nin verdiği bilgilere göre her gün eğitimli ve tecrübeli kişiler saray kütüphanesindeki kitapları getirip baştan sona kadar Ekber Şah'a okumaktaydılar. Bir okuyucunun o gün hangi sayfada kaldığını Ekber Şah'ın bizzat kendisi işaretler ve okunan sayfaya göre okuyucuya para verirdi. Kitapları dinlemekten asla sıkılmayan Ekber Şah'a okunan önemli kitapların bazıları şunlardır: Ahlâk-1 Nasırî, Kimyâ-yı Saâdet, Kâbusnâme, Gülistan, Mesnevî, Şehnâme ve bir takım tarih kitaplarıdır (Abu'l Fazl Allami, 1873, s. 103104).

Ekber Şah'ın kurduğu kütüphane o kadar büyük ve değerliydi ki şimdiye kadar onun kalibresinde bir kütüphanenin olmadığı kimi yazarlar tarafından belirtilmektedir. Kütüphanedeki bütün kitaplar elyazması olup o dönemde yavaş yavaş gelişmekte olan basılı eserlere yer verilmemiştir. Ekber Şah'ın 1605 yllında ölümünden sonra Agra Kalesi'nde bulunan hazinesinde yapılan envantere göre birçoğu antik döneme ait değerli yazarlar tarafından kaleme alınmış kitaplar sayılmış olup, söz konusu kitaplar kaliteli ciltleme ve pahalı resimlerle zenginleştirilmişti. Yaklaşık 24 bin kitabın bulunduğu kütüphanenin değeri o dönemin şatlarında 6 buçuk milyon rupi etmekteydi (Smith, 1917, s. 424).

Ekber Şah dönemi saray kütüphanesi hakkındaki bilgilerin birçoğunu Ekber Şah'ın baş veziri Ebu'l Fazl'ın kaleme aldığı Ain-i Akbar adlı eserinden elde etmekteyiz. Ebu'l Fazl saray kütüphanesinin birçok bölüme ayrıldığını bir kısmının haremde bir kısmının da harem dışında saklandığını belirtmektedir. Kitaplar öncelikle bilimsel alanlarına göre astroloji, astronomi, 
tefsir, geometri, hukuk, tıp, müzik, filoloji, felsefe, şiir, sufizm, ilahiyat ve hadis olarak alt bölümlere ayrılırdı (Datta, 1960, s. 172). Ardından diline göre Hintçe, Farsça, Grekçe, Kaşmirce ve Arapça olarak ayrı ayrı gruplandırılırdı. (Abu'l Fazl Allami, 1873, s. 103).

Ekber Şah’a babasından güçlü ve zengin bir kütüphane miras kalsa da, çıktığı seferlerde sadece Babür İmparatorluğu'nun topraklarını genişletmekle kalmamış, aynı zamanda kendi kütüphanesini de zenginleştirmiştir. Fethettiği yerlerde yöneticilere ve üst sınıfa ait kişilerin kütüphanelerinde bulunan kitapları alarak saray kütüphanesine yerleştirmiştir. Kitaplar ağırlıklı olarak Gücerat, Keşmir, Jaunpur, Bihar, Bengal ve Dekken (Güney Hindistan) gibi bölgelerdeki kütüphanelerden temin edilmiştir. Ekber Şah'ın bu tutumuna en bilindik örnek ise Gücerat'ın fethinden sonra getirttiği İtimat Han Gujrati'ye ait olan kitapları kütüphanesine dahil etmesidir (Abdul-Qadir Ibn-i-Muluk Shah, 1990, s. 205B; Mukherjee, 2001, s. 164). Bunun dişında Faizi'ye ait 4600 eserin olduğu kütüphane, Faizi'nin ölümünden sonra Ekber Şah'ın kütüphanesine taşınmıştır (Taher and Davis, 1994, s. 50). Faizi'nin kütüphanesi üç ana bölüme ayrılmış olup, birinci bölümde şiir, müzik, tıp ve astroloji, ikinci bölümde felsefe, filoloji, sufizm, astronomi ve geometri, üçüncü bölümde ilahiyat, hukuk ve tefsir kitapları bulunmaktayd1 (Datta, 1960, s. 173).

Padişah ve ailesine ait olan Saray kütüphanesinin dışında Ekber Şah döneminde ülkenin birçok yerinde kütüphaneler açılmış, kütüphanelerden Müslüman, Hindu ve diğer din ve inançlara sahip insanlar faydalanmıştır. Fatehpur Sikri'de kadınların eğitimi ve öğretimine yardımcı olması için bir kütüphane açılmıştır (Taher and Davis, 1994, s. 51). İslâmî eğitimin merkezleri olarak bilinen camiler ve medreselerde de kütüphanelerin varlığı bilinmektedir (Taher, 1992, s. 43-48).

Ekber Şah birçok eserin tercüme ettirilmesine de gayret göstererek saray kütüphanesinin zenginleşmesine katkı sağlamıştır. Filologlar sürekli Hintçe, Grekçe, Arapça ve Farsça kitapları tercüme etmiştir. Özellikle Hindular için önemli olan Mahabharata bu dönemde Nakıp Han, Abdulkadir Badauni ve Şeyh Sultan Tanesar gibi dönemin önemli âlimleri tarafından Farsçaya çevrilmiştir (Abu'l Fazl Allami, 1873, s. 104; Abdul-Qadir Ibn-i-Muluk Shah, 1990, s. 330B). Yine antik Hindistan'1 anlatan Ramayana adlı eser Badauni tarafından Farsçaya tercüme edilmiştir. Hacı İbrahim Sirhend Hindulara göre dört kutsal kitaptan biri olan Atharban 'l, Hint matematikçiler tarafından aritmetik üzerine yazılan Lilawati de Şeyh Abdul Faizi tarafından Farsça'ya çevrilmiştir. Bunların dışında Kelile ve Dimne, Haribans, Nal-daman gibi eserler de tercüme edilmiştir (Abu'l Fazl Allami, 1873, s. 105-106). Tercüme faaliyetlerinin yoğun bir şekilde yapılmasından açıkça anlaşılacağı üzere tercümeler kütüphanelerin zenginleşmesinin önde gelen nedenlerinden olmuş, düzenli çevirilerin yapılmasıyla birçok yeni kitap kütüphanelere eklenmiştir.

Özellikle sarayda bulunan kütüphanede işlerin yürütülmesini sağlayan görevliler bulunurdu. Ayrı bir binada bulunan kütüphanenin aydınlatmasına, hava sirkülasyonunun iyi şekilde ayarlanmasına özen gösterilmiş, rutubet kontrolü ve kitaplara zarar verebilecek kurtlara da dikkat edilmiştir. Saray Kütüphanesinde birçok görevli çalışmakta olup, kütüphanenin yönetiminde en yetkili kişi Nazim ya da Mutamid olarak adlandırılan kişiydi. Mutamid kendinden düşük rütbede çalışan kişileri işe alıp veya işten çıkarmakla görevliydi. Ayrıca kütüphanenin gelir ve giderleriyle de ilgilenirdi. Mutamid'in altında Muhtamin ya da Darogha adı verilen ve kütüphanenin iç yönetimine bakan görevli vardı. Yetenekli ve becerikli olması 
Hint Topraklarında Türk Kütüphaneciliğinin İzlerini Aramak: Kütüphanelerin Gelişiminde Babürlü Hükümdarlarının Rolleri (1526-1707)

Searching for Traces of Turkish Librarianship in Indian Lands: Roles of Mughal Rulers in the Development of

beklenen bu görevli, kitapların seçimi, satın alınması ve sınıflandırılmasından sorumluydu. Muhtamin'in emrinde çalışan birçok görevli vardı. Bunlar kitapları seri numaralarına göre sınıflandırmanın yanı sıra kitapların temizliğiyle de ilgilenirdi. Ayrıca kütüphanelerde Jild-saaj adı verilen ciltleme işiyle uğrasan görevli, nadir yazma eserlerin kopya edilmesi için müstensihler ve eserlerin belirli sayfalarına minyatür ve resimler yapması için nakkaşlar bulunmaktaydi (Mukherjee, 2001, s. 165).

Ekber Şah'1 diğer Babür hükümdarlarından ayıran özellik ise kütüphanecilikle ilgili faaliyetlere kişisel ilgi dışında siyasî ve dinî bir amaçla yaklaşmasıydı. Babür İmparatorluğu'nun ikinci kurucusu olarak zikredilen Ekber Şah, siyasî olarak Kuzey Hindistan bölgesinde otoritesini sağladıktan sonra farklı dinlere ve inanışlara sahip olan tebaasını tek bir din altında birleştirmeyi ummuştu. Bu doğrultuda "Dîn-i İlâhî” adında yeni bir din kurmak istedi. Dîn-i İlâhî’nin altyapısını oluşturmak için farklı dinlere mensup din adamlarıyla sohbetler ederek bilgi sahibi olurken aynı zamanda tercüme faaliyetleriyle birlikte var olan eski metinleri ortaya çıkarıp onlardan faydalanmaya çalıştığı düşünülebilir.

Ekber Şah, Babür İmparatorluğu'nun hükümdarları arasında eğitim, kitap ve kütüphane açısından bakıldığında belki de en dikkat çekenidir. Okuma yazma bilmemesine rağmen âlimlerle tartışmalara katılacak kadar bilgiliydi. Onun zamanında Babür İmparatorluğu'nun saray kütüphanesi yapılan tercüme faaliyetleri ve başka bölgelerdeki kütüphanelerden getirilen kitaplarla birlikte eşine az rastlanır bir zenginliğe ulaşmıştır. Saray kütüphanesine belli bir tasnifleme sistemi getirilirken, çalışanların görevleri de belli bir düzene göre ayarlanmış, Ekber Şah ayrıca ülke genelinde kütüphanelerin kurulup geliştirilmesine de destek vermiştir.

\section{Cihangir Dönemi Kütüphanelerin Durumu}

Babası Ekber Şah'1n ölümünden sonra tahta geçen Cihangir iyi bir eğitim almış olup, Tüzük-i Cihangir adında kendi yazdığı bir otobiyografisi bulunmaktadır. Tüzük-i Cihangir dönemin kütüphanecilik faaliyetleri hakkında bilgi veren önemli eserlerindendir. Cihangir kendinden önceki Babür hükümdarları gibi eğitime ve öğretime destek vermiştir. Bu alandaki ilk icraatı, zengin bir kişi veya seyyah öldügünde mirasını bırakacak kimseleri yoksa varlıklarının medreselerin, manastırların ve diğer binaların tamiri için devlete kalmasıdır. İkinci önemli icraatı ise çok uzun yıllar boyunca kullanılmamış ve akabinde köhneleşmiş medreseleri imar ettirerek tekrar öğrenci ve hocalara açmasıdır (Law, 1916, s. 174-175).

Hatıratından anlaşıldığı üzere Cihangir kendisine miras kalan saray kütüphanesini sadece kitaplarla zenginleştirmenin yanı sıra kütüphaneye bir de resim galerisi ekleyerek daha ihtişamlı görünmesini sağlamıştır. Onun zamanında Maktub Han hem kütüphanenin hem de galerinin yöneticisi olarak atanmıştır (Jahangir, 1909, s. 12). Cihangir, saray kütüphanesinin zenginleşmesi için fiyatı ne kadar yüksek olursa olsun el yazması eserler almaktan çekinmemiştir (Bhatt ve Majumdar, 2012, s. 246). Saray kütüphanesi dışında Cihangir'in kendisine ait özel bir kütüphanesi mevcut olup, ataları gibi kütüphanesini yanında taşımayı adet edinmiştir. Gücerat'a gittiğinde kendisini ziyarete gelen şeyhlere hilat giydirip toprak tahsis ederken, aynı zamanda kendisine ait özel kütüphanesinde bulunan Tafsir-i Kashshaf, Tafsir-i Husaini ve Rauzatu-l Ahbâb gibi kitapları hediye olarak vermiştir. Hediye ettiği kitapların 
arkasına da Gücerat'a geliş tarihi ve kitapları veriş tarihini yazmıştır (Jahangir, 1909, s. 439440).

Cihangir'in kitaplarda resimlerin kullanılmasına önem verdiği dikkat çekmektedir. Bu sebeple dönemin önemli nakkaşlarından Mukarrab Han'1 Goa'dan getirterek kendi yazdığ1 Tüzük-i Cihangir adlı eserine resimler yapması için görevlendirmiştir. Hat sanatına da ayrı bir önem veren Cihangir dönemin ünlü hattatlarını hediyelerle ödüllendirmiştir. Örneğin Şeyh Farid Bakhari’ye hilat giydirip mücevherlerle süslenmiş bir kılıç, kalem ve hokka takdim ederek Bakhari'ye "kalem ve kılıcın efendisi" anlamını yüklemiştir (Datta, 1960, s. 71). Cihangir'in önemsediği bir başka grup kâtiplerdi. Tüzük-i Cihangir'in on iki yılı kapsayan bölümünü yazdıktan sonra özel kütüphanesinde çalışan kâtiplere eserin birçok kopyasının yapılmasını emretmiş ve böylece yapılan kopyaları özel hizmetçilerine, yöneticilere ve ülkedeki asilzadelere göndererek onlara yol gösterici olmasını istemiştir. Bu bağlamda tamamlanan kopyalardan ilkini arkasına tarih ve yer yazarak en büyük oğlu olan Şah Cihan'a vermiştir (Jahangir, 1914, s. 26-27).

Cihangir'in babasının kendisine miras bıraktığı kütüphaneyi geliştirmeye devam ettiği görülmektedir. Özellikle kütüphaneye resim galerisi eklenmesi, kitaplara minyatürlerin çizilmesi Cihangir'in getirdiği dikkat çeken yeniliklerin başında gelmektedir. Cihangir'in geliştirdiği saray kütüphanesine oğlu Şah Cihan da gereken önemi vermiş, tercüme faaliyetleri başta olmak üzere Avrupa'dan getirilen kitaplarla kütüphane zenginleştirilmiştir.

\section{Şah Cihan Dönemi Kütüphanecilik Faaliyetleri}

Genellikle mimarî yapılara verdiği önemle tanınan Şah Cihan dünyanın yedi harikasından biri olarak kabul edilen Tac Mahal'i yaptırmış ve Babür İmparatorluğu'nun başkentini (Şahcihanabad) Agra'dan Delhi’ye taşıdığında Kırmızı Kale ve Cuma Mescid gibi güzide mimari yapıları Hint topraklarına kazandırmıştır. Bununla birlikte Şah Cihan’ı öne çıkaran özelliklerinden biri de şairlere, tarihçilere ve din adamlarına destek vermesidir. Sanskritçe bilen ilim adamlarını destekleyip Upanişadlar ve Bhagvad Gita gibi önemli Hindu metinlerin Farsça'ya tercüme edilmesini sağlamış (Bhatt, 1995, s. 35) Abdul Hamid Lahori, Aminai Qazwini, Muhammad Salih, Inayat Khan gibi tarihçileri himayesine alarak onlara çalışmalarında destek olmuştur. Böylece bahsedilen tarihçilerin kitapları başta saray kütüphanesi olmak üzere Hint altkıtasındaki kütüphanelerde yerlerini almıştır. Bu sayede hem saray kütüphanesi hem de ülkedeki kütüphaneler kayda değer bir zenginlik kazanmıştır. Öte yandan devletin başkenti Delhi'ye taşındıktan sonra burada büyük bir okul kurduran Şah Cihan, ayrıca Dâr-ul-Bakâ adlı eski bir okulun onarılıp hizmete sokulmasını sağlamış ve bu sayede okullara ait kütüphaneler geliştirilerek halkın hizmetine sunulmuştur (Datta, 1960, s. 72).

Şah Cihan ile ilgili ilginç anekdotlardan birisi akşamları uyumadan önce kendisine kitaplar okunmasıdır. Okuma yeteneği gelişmiş kişiler, Şah Cihan'ın yatak odasına bitişik ayrı bir bölmeden sesli bir şekilde kitap okurlardı. Şah Cihan genellikle seyahatname, din adamlarının ve peygamberlerin yaşantılarını ve önceki kralların hayat hikâyelerini dinlemekten hoşlanırdı. Özellikle ataları Timur ve Babür Şah'ın hayat hikâyelerini dinlemek Şah'ın ilgisini çekerdi (Sarkar, 1912, s. 174).

Şah Cihan döneminin dikkat çeken bilgilerinden biri Alman seyyah Mandelso-Harris tarafından verilmiştir. Harris, saray kütüphanesinde 24 bin civarı çok iyi ciltlenmiş kitap 
Hint Topraklarında Türk Kütüphaneciliğinin İzlerini Aramak: Kütüphanelerin Gelişiminde Babürlü Hükümdarlarının Rolleri (1526-1707)

Searching for Traces of Turkish Librarianship in Indian Lands: Roles of Mughal Rulers in the Development of

olduğunu belirtmiş̧tir. Aynı sayının Ekber Şah döneminde de verildiği düşünülünce Ekber Şah'ın ölümüyle birlikte kütüphanelere yeni kitapların eklenmediği düşüncesi ortaya çıkmaktadır. Ayrıca sayım sisteminde bir farklılık olması, kütüphanede bulunan kitapların hediye veya bağış olarak başkalarına verilmesi ve son olarak Harris'in ciltlenmemiş olan kitaplar hakkında bilgi alamaması verilen rakamın eksik veya yanlış olmasının sebeplerinden birkaçıdır (Taher and Davis, 1994, s. 53).

Babürlüler dönemi Hindistan birçok misyoner ve Avrupalı Cizvit'in durağı olmuştur. Şah Cihan döneminde de devam eden bu ziyaretlerde Şah'a Avrupa'da basılmış kitaplar hediye edilmiş, böylece Avrupalıların getirdiği matbu kitaplar saray kütüphanesinde yavaş yavaş yer bulmaya başlamıştır (Taher and Davis, 1994, s. 53).

\section{Evrengzib Döneminde Kütüphaneler}

Babür İmparatorluğu'nun son güçlü padişahı olan Evrengzib Hint tarihinin en tartışmalı yöneticisi konumundadır. Evrengzib'in aşırı dindar olduğu ve bu yüzden Hindulara ait tapınakları yıktığı ve onlara pek görev vermediği birçok çevre tarafından kabul edilmiştir. ${ }^{2}$ Ancak entelektüel anlamda bakıldığında Evrengzib'in Müslüman ilim adamları kadar Hindu ilim adamlarına da değer verip onları koruduğu görülmektedir. Birdad, Bhushan ve Brinda gibi Hindu şair ve âlimler Evrengzib tarafindan desteklenmiştir. Aynı şekilde Farsça'ya hâkim olan Sujan Rai Khatri, Wamat Khatri, Rai Brindaban, Iswardas Nagar ve Bhimsen gibi Hindu âlimleri koruması altına alarak, onlara saray kütüphanesinin kapılarını sonuna kadar açmıştır (Taher and Davis, 1994, s. 54). Evrengzib, yönetimde kaldığ 49 yıl boyunca birçok sefer yapmış, Babür İmparatorluğu'nun hazinesinin büyük bir kısmının savaşlarda harcanmasına sebep olmuşsa da kendinden önceki hükümdarlar gibi kitaplara, ilim adamlarına ve kütüphanelere değer vermiş, kütüphanelerin gelişmesi için çaba sarf etmiştir.

Evrengzib iyi bir askerî ve yönetici olmasının yanı sıra dindar bir kişiydi. Her gün öğle namazından sonra ya Kur'an-1 Kerim ya da İslam'a dair kitaplar okurdu (Sarkar, 1912, s. 181). Her gün kurulan Divan'da gelen yazıları okur ve kendi el yazısıyla emirler yazarak ülkenin dört bir tarafına gönderirdi (Sarkar, 1912, s. 28). İslam hukuku ve ilahiyata meraklı olan Evrengzib tanınmış ve başarılı hukuk adamlarına Molla Nizam'ın önderliğinde Fatawa-i Alamgiri in ${ }^{3}$ derleyip toparlaması emrini vermiştir. Ayrıca tefsir, hadis ve fikıh üzerine yazılmış kitapların toplanıp saray kütüphanesine katılmasına özen göstermiştir. (Bhatt, 1995, s. 35). Evrengzib ülkenin birçok yerinde okullar ve kütüphaneler açılmasını sağlamıştır. Özellikle camilerde yer

\footnotetext{
${ }^{2}$ Özellikle kolonyal dönemde ortaya atılan bu görüş İngilizlerin böl, parçala ve yönet politikasının bir parçası olup, Hindu ve Müslüman halkı birbirine düşman etme yollarından biriydi. Dindar yönü ön plana çıkarılan Evrengzib'in bir takım sebeplerden dolayı Hindulara ait birkaç tapınağı yıktırması ve cizye vergisini geri getirmesi İngiliz tarihçiler tarafından kullanılarak İngiliz yönetiminin daha iyi olduğu algısı yaratılmaya çalışılmıştır. Konu hakkında detaylı bilgi için bkz. (Truscke, 2018).

${ }^{3}$ Fatawa-i Alamgiri diğer bir deyişle Fatawa-i Hindiyye Sünni Hanefi mezhebi doğrultusunda Babür hükümdarı Evrengzib'in emriyle 1664-1672 yılları arasında yazılmış bir fetva kitabıdır. Evrengzib fikıh kitaplarında dağınık halde bulunan görüşlerin tasnif edilerek düzenlenmesini emretmiş, kitap bu doğrultuda Burhanpurlu Şeyh Nizam başkanlığında onar kişilik birer heyetle yazılmıştır. Evrengzib'in bu çalışma için yaklaşık 200,000 rupilik bir harcama yaptığı belirtilmektedir. Fatawa-i Alamgiri, İngilizler Hint Yarımadası'nın kontrolünü ele geçirinceye kadar İslam hukukunun uygulanmasında en önemli kaynaklardan biri olmasının yanı sıra İngiliz mahkemelerince de gerektiğinde başvurulan bir eser olmuştur. (Özel, 1989, s. 365-366).
} 
alan kütüphaneler bu dönemde daha da artmış ve halkın kullanımına sunulmuştur (Patel ve Kumar, 2001, s. 6). Bunun dışında Dekken bölgesini fethettikten sonra Bidar'da bulunan ve Bahmani Sultanlığı'nın ünlü veziri Muhammed Gawan'ın kütüphanesini de saray kütüphanesine kattığı bilinmektedir (Datta, 1960, s. 74).

\section{Sonuç}

Türkler tarih boyunca askerî özellikleri ve başarılı teşkilatlanmaları ile bilinen bir millet olmuştur. Askerî yetenekleri sayesinde gittikleri coğrafyalara egemen olurken, iyi bir teşkilatlanmayla birlikte devletler kurup buraları yönetmişlerdir. Türklerin Orta Asya'dan göç edip, devlet kurduğu ve uzun yıllar hüküm sürdüğü yerlerden birisi de Hint Yarımadası'dır. Türkler, Hint coğrafyasına başlangıçta yurt gözüyle bakmasalar da Delhi Türk Sultanlığı ve Babür İmparatorluğu ile birlikte yüzyıllar boyunca Hindistan'da bir Türk yönetimi kurdular. Askerî ve siyasî anlamda Hint Yarımadası'nın büyük bir kısmına egemen olan Türkler, özellikle Babür İmparatorluğu döneminde kültürel açıdan önemli izler bıraktılar.

1526-1707 yılları arası hüküm süren Babür hükümdarlarının entelektüel yapıları ve kütüphanelere olan yaklaşımlarının ele alındığı bu çalışmada görülmüştür ki hükümdarlar, kendilerini geliştiren ve âlimlere değer veren kişilerdi. Babür Şah ve Cihangir otobiyografilerini yazarken, Hümayun, Ekber Şah, Şah Cihan ve Evrengzib, dönemin vakanüvislerini yaşanan gelişmeleri kayıt altına alması için desteklemişlerdir. Ekber Şah okuma yazma bilmemesine rağmen kendisine özel okuyucular tutarak onlardan kitaplarda yazılanları dinlemiştir. Hatta Ekber Şah'ın emriyle kütüphane tasnif edilirken koleksiyon, tercüme faaliyetleri ve kitap çeşidi açısından zenginleştirilmiştir.

Babür hükümdarlarının tarih kitapları başta olmak üzere dini kitapları okumayı tercih ettikleri görülmüştür. Bunların yanı sıra seyahatnameler, peygamberlerin yaşantıları, önceki padişahların hayat hikâyeleri ve astronomi ile ilgili kitaplar da ilgilerini çekmiştir. Saray kütüphanesine ait bölümde kitapların ciltlenmesi ve resimlerle zenginleştirilmesi için özel çalışma alanlarının yapıldığı dikkat çekmektedir. Ayrıca kaligrafi hükümdarlar tarafından önem verilen bir sanat olmuştur.

Hükümdarların hem saray kütüphanesi hem de ülke genelindeki kütüphanelerin gelişiminde aktif rol oynadıkları görülmüştür. Saray kütüphanesinde mütercim, müzehhib, mücellid ve hattat istihdam edilmiştir. Ülke genelinde ise açılan eğitim öğretim yerlerinin hepsine kütüphane eklenmesine özen gösterilmiştir. Özellikle Cihangir'in yıkılmaya yüz tutmuş eğitim yerlerini imar ettirmesi ve bunlara sahipsiz miraslardan fon sağlaması dikkat çeken icraatlardan biridir.

Babür hükümdarları ile ilgili dikkat çeken bir durum da başka kişilere ait kütüphaneleri saray kütüphanesine taşımaları olmuştur. Burada yağmacılıktan ziyade kitapların saray kütüphanesinde daha iyi muhafaza edileceği düşüncesiyle böyle bir girişimde bulundukları değerlendirilmektedir. 
Hint Topraklarında Türk Kütüphaneciliğinin İzlerini Aramak: Kütüphanelerin Gelişiminde Babürlü Hükümdarlarının Rolleri (1526-1707)

Searching for Traces of Turkish Librarianship in Indian Lands: Roles of Mughal Rulers in the Development of

Libraries (1526-1707)

\section{Kaynakça}

Abdul-Qadir Ibn-i-Muluk Shah (Al-Badaoni) (1990). A History of India muntakhabu-t-tawarikh. (G. S. A. Ranking, Çev.). C. 1. Yeni Delhi: Atlantic Publishers.

Abdul-Qadir Ibn-i-Muluk Shah (Al-Badaoni) (1990). A History of India muntakhabu-t-tawarikh. (G. S. A. Ranking, Çev.). C. 2. Yeni Delhi: Atlantic Publishers.

Abu'l Fazl Allami (1873). Ain-i akbari. (H. Blochmann, Çev.). C. 1. Kalküta: The Baptist Mission Press. Abu'1 Fazl Allami (1907). The akbarnama. (H. Beveridge, Çev.). C. 1. Kalküta: Royal Asiatic Society. Aka, İ. (1997). Hândmîr. Türkiye Diyanet Vakfi Ansiklopedisi, 15, İstanbul: TDV Yayınları, 550-552.

Alparslan, A. (1977). Babur'un icad ettiği baburî yazı. Journal of Turkology, 19, 207-211.

Ayyubi, N. ve Kaymaz, N. (1964). Hindistan Türklere neler borçludur?. Tarih Araştırmaları Dergisi, 2 (2), 277-283.

Babür (2000). Babürnâme "Babür'ün hatıratı". R. R. Arat (Yay. Haz.). Ankara: Kültür ve Turizm Bakanlığı Yayınları.

Bhatt, R. K. (1995). History and development of libraries in India. Yeni Delhi: Mittal Publications.

Bhatt, R. K. ve Majumdar, S (2012). "Libraries through the ages in India: Sojourn from Palm Leaf to Palmtop". Libraries in the early 21 st century, An international perspective. C. 2. Ravindra N. Sharma (Ed.). Göttingen: Hubert \& Co.

Chandra, S. (1990). Medieval India A history textbook for class XI. Yeni Delhi: The National Council of Educational Research and Training.

Chandra, S. (2003). Medieval India from Sultanat to the Mughals. C. 2. Yeni Delhi: Har-Anand Publications.

Chandra, S. (2017). Medieval India from Sultanat to the Mughals: Delhi Sultanat (1206-1526). C. 1. Yeni Delhi: Har-Anand Publications.

Dale, S. F. (2018). Babur: Timurid prince and mughal emperor, 1483-1530. Yeni Delhi: Cambridge University Press.

Datta, B. K. (1960). Libraries \& librarianship of ancient and medieval India. Delhi: Atma Ram.

Elliot, H. M. (1872). The history of India: as told by its own historians. The Muhammadan period. C. 4. Londra: Trübner \&Co.

Jahangir (1909). The Tuzuk-i-Jahangiri; or, memoirs of Jahangir. C. 1. (A. Rogers, Çev.). H. Beveridge (Ed.). Londra: Royal Asiatic Society.

Jahangir (1914). The Tuzuk-i-Jahangiri; or, Memoirs of Jahangir. C. 2. A. (Rogers, Çev.). H. Beveridge (Ed.). Londra: Royal Asiatic Society.

Jouher (1832). Tezkereh al vakiat, or private memoirs of the Moghul emperor Hümayun. Major (C. Stewart, Çev.). Londra: ?.

Konukçu, E. (1998). Hümâyun. Türkiye Diyanet Vakfi Ansiklopedisi, 18, İstanbul: TDV Yayınları, 481483.

Law, N. N. (1916). Promotion of learning in India during Muhammadan rule. Londra: Longmans, Green and Co.

Mahomed Kasim Ferishta (1909). History of the rise of the Mahomedan power in India till the year A.D. 1612. (J. Briggs, Çev.). C. 2. Kalküta: R. Cambray \&Co.

Mukherjee, S. (2001), Royal Mughal ladies and their contributions. Yeni Delhi: Gyan Publishing House. 
Özel, A. (1989). el-Âlemgîriyye. Türkiye Diyanet Vakfı Ansiklopedisi. C. 2. İstanbul: TDV Yayınları, 365-366.

Patel, J. ve Kumar, K. (2001). Libraries and librarianship in India. Westport: Greenwood Press.

Sarkar, J. (1912). Anecdotes Of Aurangzib And Historical Essays. Kalküta: M. C. Sarkar \& Sons.

Seydi Ali Reis (1975). Mir'at-ül memalik ülkelerin aynası. N. Akyıldız (Yay. Haz.). İstanbul: Kervan Kitapçıllk.

Smith, V. A. (1917). Akbar the great Mogul, 1542-1605. Oxford: Clarendon Press.

Taher, M. (1992). Mosque Libraries: A Bibliographical Essay. Libraries \& Culture. 27(1), 43-48.

Taher, M. ve Davis, D. G. (1994). Librarianship and library science in India: An outline of historical perspectives. Yeni Delhi: Concept Publishing Company.

Truscke, A. (2018). Aurangzeb: The man and the myth. Yeni Delhi: Penguin Books. 